\title{
Detecting a Literary Future in the Historical Past: The Gibraltar Case
}

\author{
John A Stotesbury \\ University of Eastern Finland, Joensuu
}

\begin{abstract}
Until the present millennium, very little creative literary writing in either English or Spanish had been published in the British colonial enclave of Gibraltar. Given the small population size of the autonomous community of some 30,000 people, it was considered unlikely that a "national" literary culture could form. In the course of the past decade, a handful of dedicated writers have published a noticeable amount of fiction, all of which is concerned with establishing a recognized Gibraltarian literary identity. The present article, while not arguing for the permanence of a Gibraltarian national literary culture, attempts to trace some of the ways in which a small, unified, geopolitical territory has attempted to tell its own story.
\end{abstract}

Key words: Gibraltar, identity, historical crime fiction, siege, memory, postcolonial, museumification

\section{Introduction}

In the broad field of literary studies there are probably relatively few opportunities to focus on the emergence of a new, contemporary national literature. Most cultures have passed through many stages in the process of shaping of their communal stories: their narratives reveal and simultaneously conceal complex tales of past experience and present and future aspirations. The tales may be shaped from conflicting narratives and from narratives whose sources have faded from memory long ago. In the case of Gibraltar, however, it may be argued that in the decades since the Second World War the largely urban community of some 30,000 individuals, who stem from a variety of backgrounds, both European and African, largely, but not solely, Mediterranean, has for geopolitical and domestic reasons - the return of thousands of evacuees after the War; the lasting imposition of a Cold War-like relationship with Spain; the decline in British global military ambitions - begun to assume a new and very different common identity. It is this emergent sense of a new communality that is now persuading a few local writers to explore its multifaceted origins, framing narratives that have their source in experiences that have been generally forgotten by the local populace as much as by a wider, global readership. The novelty of this process is striking: prior to the year 2005, the publication of literary texts by Gibraltarians writing in either Spanish or English was 
sporadic, and sparse; now, however, a tiny handful of Gibraltarians have produced a substantial body of writing that deserves critical attention. The present article is modest in scope, focussing in the main on a single title in the intensive collaborative literary production of two writers, Sam Benady and Mary Chiappe, whilst attempting to provide a partial foundation for future literary-critical work.

\section{Fictionalizing History}

Gibraltar has shown itself in recent times to be remarkably capable of surviving as a self-ruling entity, where referenda have demonstrated the reluctance of its multi-ethnic population of some 30,000 to dilute its political and economic difference from Spain. Despite their self-evident interdependence, Gibraltarians and their immediate neighbours in the considerably larger Spanish communities of La Línea de la Concepción, across the land-frontier to the north, and Algeciras, to the west, a few kilometres across the Bahía de Algeciras/Bay of Gibraltar, remain separated by a common history that extends well beyond the formal acquisition of the colony by Britain as a result of the signing of the Treaty of Utrecht in 1713. An even older significant aspect of that shared difference (as I have remarked elsewhere ${ }^{1}$ ) has been the proliferation of sieges of the Rock, including an iconic series of some fourteen blockades that commenced in the early $14^{\text {th }}$ century and culminated in the Great Siege of the British military colony from June 1779 to February 1783. The prominence and geopolitical location of Gibraltar and its Rock have evidently endowed it with a susceptibility to besiegement, and it can well be argued that the full and partial economic blockades that have continued into recent times ${ }^{2}$ have paid more than lipservice to that communal experience of hardship and suffering.

My intention in this brief study is, however, only indirectly linked with the historical experience of siege. Given its three centuries of exposure to British influence of all kinds, it would appear to be inevitable that literary expression of local cultural identity would have emerged, especially in the now 70 years of the post-Second World War period, with the return of most of Gibraltar's wartime civilian evacuees and the entrenchment of an education system founded on the metropolitan English model (its two main secondary schools are based on the UK comprehensive model of the 1970s) and on the English language ${ }^{3}$ as the principal medium of instruction. This has not, however, been the case. Writing in 2010, albeit with somewhat dated references, the Spanish scholar César Domínguez refers to the opinion of the poet Trino Cruz Seruya that "Gibraltarian literature is a literature nonata (not yet born)", Crucially, he concurs with Seruya's suggestion that the relative absence of a local Gibraltarian literary culture has been the result of its having become "lost within itself or moving in circles" 5 .

That Seruya's reading - which I would regard as largely accurate - dates back to as recent a date as 2004 underlines the apparent significance of more recent literary activity in the colony. Even now, it would be difficult to argue that a "national" 
Gibraltarian literature has been established: it is simply too sparse. Nevertheless, a tiny handful of writers has started - as one of them, M.G. [Mark Gerard] Sanchez, has asserted in interview with the Italian scholar Esterino Adami - to respond to the challenge that Gibraltarians "need to have our own representative voice - and not just let ourselves be represented by outsiders"6. Elsewhere, Sanchez has suggested that his writing is primarily concerned with "giving Gibraltarians a linguistic and cultural space for themselves. [...] [I]f we don't start writing about ourselves, we run the risk of being presented to the world solely through the prism of others' perceptions"7. Since 2007, Sanchez's writing, most of it self-published, has become both substantial and varied, consisting of two volumes of short fiction, several novels, an anthology of allusions to Gibraltar made by literary "outsiders", and an array of cultural and historical essays; in brief, Sanchez's endeavour is self-evidently to supply a solid foundation for both his own and other Gibraltarians' literary work, an assertion of place, language, history: rootedness.

On the surface, there is an immediate and striking contrast between Sanchez's work and the recent collaborative writing of two other Gibraltarians, Sam Benady and Mary Chiappe. Their most substantial work (in addition to a scattering of individually authored fictional - and other $-\operatorname{texts}^{8}$ ) consists of a seven-part series of imaginative crime novels, all with Gibraltarian settings located within a specific historical period broadly speaking, from the 1790 s to the 1820 s - focused through the identity of an amateur detective, Giovanni Bresciano, son of an immigrant Italian ship chandler, who in the course of the series himself becomes a chandler and merchant whilst simultaneously functioning as an amateur investigative eye.

Thus, even at first glance it becomes clear that Benady and Chiappe have set out to devise a potentially complex formula for their fiction: a Gibraltar imagined at an early moment in its colonial formation, at a conflicted period in its history, with a protagonist whose identity is hybrid, both Gibraltarian and British. In their second title, Fall of a Sparrow (2010), Bresciano is both fledgling recruit to the local British garrison and also a character inching towards an awareness of the ramifications of his self-appointed apprentice role as crime investigator; but he is also credibly hybrid in his imperial identity - his mother is English, while his father is a first-generation Gibraltarian, with Genoese origins. In addition, as the authors themselves have indicated in interview, Benady's primary interest has been in "Gibraltar history and forensic and medical detail," while Chiappe's has been in the "social history of the period", aims that find their focus in and through Bresciano's role as an increasingly observant, investigative Gibraltarian citizen.

In brief, for their historical settings the seven novels in the series (at the moment of writing, the seventh, The Dead Can't Paint: Bresciano and the French Inheritance, has very recently appeared) have a fairly random span of almost forty years, although also with links to key moments in the local history of the period, starting with that of the 
second completed novel, Fall of a Sparrow (2011), in 1779 (the Great Siege) and ending with the forthcoming title, The Dead Can't Paint, in 1817 (linked with the visit of a French exploration vessel the Uranie, bound for the South Seas). It can readily be noted, however, that the sequence of the time-settings does not entirely coincide with the writing and publication of the novels themselves, and the bulk of my attention in this study will indeed be paid not to the first to be published, The Murder in Whirligig Lane (2010; set in 1813; Yellow Fever epidemic) but to the second, Fall of a Sparrow, set in 1779-1780 amidst the iconic Great Siege of 1779-1783). These titles have been succeeded by The Pearls of Tangier (2011; set in 1789; William Lempriere's visit to Morocco ${ }^{10}$ ); The Prince's Lady (2012; set in 1790; Prince Edward, King George III's fourth son, in Gibraltar); The Devil's Tongue (2013; set in 1793; start of French Wars); and Death in Paradise Ramp (2014; set in 1802; the "licentious" Duke of Kent and the 1802 Gibraltar Mutiny). At the end of this remarkably compact series, the authors aver that, between his first case, at the age of 18 , and his last, not only has the protagonist survived to the age of 55 but "Bresciano lives on!"11.

The first of the Bresciano novels, The Murder in Whirligig Lane, may in some senses be read as the two authors' own "apprenticeship" piece in collaborative storytelling, but the very title of the novel, with its assertive deployment of the definite article within the context of a now-extinct but historical place-name, suggests an intention to recall an event that, despite its fictionality, can be imagined as part of a collective memory: essentially, a reconstructed Gibraltarian experience. As popular reviewers have noted, the plot of this first novel in the series is coherent, and the solution of the crime plausible ${ }^{12}$. Fall of a Sparrow, in contrast, appears to mark the authors' growing awareness of the complexity of the task in hand, as already mentioned above: "to show our community in the process of its formation", to create a Gibraltarian narrative, and to explore some of the origins of the present-day community. As Benady has informally commented in response to a question concerning allusions to some of the named characters in this and other novels,

We used real Gibraltarians where we could [e.g., in The Devil's Tongue]: Menahem Benady was my g-g-g-grandfather and was a shoemaker. Abraham Hassan was a cousin 4 times removed and did volunteer during the Siege. Sgt Miles is Mary's husband's g-ggrandfather and was in the first Gib police force (later, in 1830) and there are others. [... Jane Austen's] Capt Wentworth started it all -I then found it amusing [in The Murder in Whirligig Lane] to have him read Sense and Sensibility ${ }^{13}$.

It may also be noted that in the Cast of Characters included at the start of Fall of a Sparrow, the authors have listed the names of "real historical personalities" in bold - 
including the Governor of Gibraltar, General Eliott, and, notably, that of Lieutenant John Drinkwater, "Diarist of the Siege" - while adding a secondary allusion to the fictional cast: "[t]he others are no less real to us" (n.pag.).

The fictionalization of the historical moment is both transparent and persuasive. The story effectively starts in 1780, "eighteen long, hungry months [...] since the start of the Spanish blockade" (p. 5). The Siege conditions are reflected in the protagonist's symbolic view of his home, where he arrives to reveal that he has joined the local British military forces in defence of his community: "the large room [...] was the centre of family life, but the house seemed empty" (p. 7) - the symbolism of the home requires populating with human relationships, which in the construction of the communal story necessarily undergo threats to their survival in the form of malnutrition and disease.

An immature eighteen year-old, Giovanni Bresciano stands out from his fellow soldiers as an individual who is "curious to hear more" (p. 28) from them concerning the violence suffered by a fellow soldier, Jamie Macfarlane, whose ethnic "difference" as a Scot eventually proves crucial in the solution of the mystery surrounding his death. In this regard, Bresciano's role is to convey curiosity and then suspicion: has Jamie suffered accidental violence and then, as a result of his damaged mind, committed suicide, or has he become the victim of murder? The first stage is for the fledgling amateur detective to discover for himself the "only rational explanation" (p. 31), and then to convince others, firstly a childhood friend and fellow local recruit, Abraham Hassan, whose simple role is to indicate the route that Bresciano must take as an investigator: "Giovanni, you have to look at the actual facts carefully" (p. 43). This process becomes crucial to Bresciano's detective maturation after Jamie's death by hanging, where the search for the location of a missing key becomes symbolic as well as factual.

The second stage in Bresciano's detective apprenticeship is then to consolidate suspicions through detailed consideration of others' potential motives. Again, his mentor Abraham acts as guide: "You have given me a number of names of people who might have had a grudge against Jamie, but have you cited a single powerful motive?" (p. 85). This dilemma continues through much of the novel, with the narrative voice, at a mid-point in the investigation, reminding the reader that "[w]hile Bresciano had the intelligence to resolve the puzzles that Jamie's death faced him with, he had more imagination than organizational skills and his investigation was lurching on from one random idea to the next. He was himself aware of it: he knew he should have looked for the key sooner" (p. 121).

Perseverance, naturally enough, eventually pays off: Bresciano gathers evidence, harbours his suspicions, and enhances his own understanding of the process of death itself by questioning the more experienced regiment cook about the onset of rigor mortis in human cadavers: 
"No! I mean, when you find a dead body, how can you tell when he died?"

"Most dead bodies I seen 've bin on the battle field. [...] Funny that. Sometimes they was limp when it 'ad all just 'appened. An' sometimes, when we 'ad to wait to collect the dead, it were a different tale. Stiff as a board they'd be. Awful - lyin' there all twisted and stiff like wooden dolls. Been dead for hours. And 'ere's a strange thing. [...] We'd 'aul away to get these rigid corpses moved, sweatin' over it [...] and if we could 'ave waited to the next day, the job would've been that much simpler. That's it, you see: first you're floppy, then you go all stiff and then you go floppy again".

(Benady and Chiappe "The Murder in Whirligig Lane”, pp. 174-175)

The "naive" learning process involved in the honing of Bresciano's suspicions and his accumulation of keys to the resolution of the crime eventually fails to direct him by means of rationalization to reveal the identity of the perpetrator. Instead, his assiduous pursuit of misleading lines of inquiry places him in immediate danger of becoming the killer's next victim. But Bresciano now understands the process that has led him into danger, and his future as an occasional detective who will act in civilian life on behalf of his community, Gibraltar, is ultimately certified by the (historical) Governor of Gibraltar, General Eliott, himself: "I congratulate you on as pretty a piece of deductive work as I have seen" (p. 283).

\section{Reading the "Popular" Text}

Thus, it may be asserted that, superficially, the Bresciano series appears to bear most, if not all, of the hallmarks of a subgenre that Stephen Knight has described, somewhat dismissively, as typical of historical crime fiction: "[M]any periods and locations are used to combine the knowledge-rich security of historicism with elementary crime fiction plots. The link often made to the "cozy" [crime fiction] is credible in that the politics of historical crime fiction are basically traditional, including in terms of gender and race" (Knight 2010:225). According to the Wikipedia entry (which in this case may be regarded as uncontroversial), the concept of "cozy" crime fiction or mystery can also be considered as a positive marketing ploy: "also referred to simply as 'cozies,' are a subgenre of crime fiction in which sex and violence are downplayed or treated humorously, and the crime and detection take place in a small, socially intimate community". The appeal of the "cozy" is reportedly strongest amongst a female readership, thus tapping into the burgeoning gender politics of the past two or three decades ${ }^{14}$.

In light of the stand-off between Knight's dismissive view and the intriguing but fragmented approaches to the "cozy" subgenre suggested by its authors, publishers and 
readership, my approach has been to read Benady and Chiappe's fiction in terms of a complex attempt on their part to investigate not only an imaginary crime (i.e., a murder mystery, narrativized within conventional literary constraints) but also their attempt to investigate and explore valid methods for re-creating a historical cultural narrative, including its actual telling as a "tale". As Sanchez has emphasized, the narrative of Gibraltar is always at risk of over-simplification in the views and narratives of outsiders, with the result that the indigenous perspective becomes overlooked and ignored in the modern world. Arguably, this may well be a common experience in colonized cultures. Hence, while my initial reading of the Benady/Chiappe narratives has been in terms of their presentation of a constructed "memory" of a fictional character, it is also Bresciano's community - Gibraltar - that not only has its own roots embedded in "real" place and time but also has its own ongoing, imaginary connections with present times. As Benady has commented, "we aimed to show our community in the process of its formation, with a backdrop of real events - the Siege, the epidemic, etc.," which Chiappe has augmented with the comment: "though [we] never formulated such a purpose per se"; predictably, like many effective story-tellers, their stated primary aim has been "to tell a good story"16.

A telling moment in my recent email interview with the authors is contained in another chance observation of Sam Benady's when he suggests that a secondary aim of their writing, from his perspective, has been "to bring Gibraltar history to our reading public," modestly adding in parentheses "(mostly Gibraltarian!)". For Benady and Chiappe, the problem of distribution and readership has been compounded by publication that has been only local, and thus, while there may be some ambiguity in Benady's response, there must also be some wryness in his consideration of the extremely limited scope locally for cultivating a readership: do the Bresciano narratives appeal solely to a Gibraltarian readership, depending on their insiders' familiarity with the historical referents, or can the authors design their narratives for consumption by, say, a British public with a partial awareness of the Rock as an imperial icon, or eventually, perhaps in translation, by a future, hypothetical Iberian readership, perhaps one whose own perspective on Gibraltar has undergone "translation"? ${ }^{16}$

Where the Bresciano novels coincide with general descriptions of post-colonial crime fiction (as opposed to colonial narratives produced by "settler" authors) may be seen, at least in part, in the identity of their protagonists:

Post-colonial detectives are always indigenous to or settlers in the countries where they work; they are usually marginalized in some way, which affects their ability to work at their full potential; they are always central and sympathetic characters; and their creators' interest usually lies in exploration of how these detectives' approaches to criminal 
investigation are influenced by their cultural attitudes. (Christian, "Introducing the Post-Colonial Detective", p. 2.

Christian concludes from this generalization that "books featuring post-colonial detectives are interesting not only because of their plots and the quality of their writing but because of their revelations of diverse cultures" (p. 2).

For obvious reasons, this would appear to be problematic in the context of historical crime fiction emerging from a culture such as that of Gibraltar: Giovanni Bresciano is by no means a "post-colonial" protagonist. Equally, Gibraltar, situated at the present moment between its self-governing status as the most populous of Britain's remaining overseas territories and its historical dilemma as a geopolitical appendage to the Iberian land-mass, nicely complicates and frustrates any quest for a satisfactory categorization. Christian's discussion of post-colonial detective protagonists seems, nevertheless, to provide a potential solution. He suggests that "these [post-colonial] detectives are in process, they are learning, adjusting, changing, compromising, rejecting, resisting. They are not heroes of the resistance, out to destroy the oppressor. They are all employed, whether publicly or privately - they answer to employers" (p. 13). In this view, fictional detectives in the post-colonial process function in an apprentice capacity, and play a conservative role - their function is, after all, to restore order and equilibrium to their community rather than to re-form it. In brief, their role, from a textual perspective, with the unravelling of the crime, is for a community and its individual members to discover how to become again what they have been previously. But they have also to create a new consciousness of how their previously secure past cannot be restored: violence has occurred, and the victim(s) and their community have undergone an unwilled transformation. On our behalf, as readers, Christian suggests, such investigative characters undertake a form of surveillance, "observation of both the empire and the indigenous culture; the observation of disparities, of ironies, of hybridities, of contradictions. Now the surveillance is not for imperial dominance, though, but for the restoration of what is right" (p. 13).

Now that the Bresciano series has been completed, it doubtless deserves more extensive treatment than this initial discussion. An especially provocative approach could perhaps be based on Jose F. Colmeiro's discussion of the Spanish detective as "cultural other" in Carlos G. Reigosa's Galician vernacular Crime en Compostela (1984). Foremost in Colmeiro's reading of Reigosa is his speculation that the "old city" of Santiago de Compostela "is the real protagonist of the novel, having become a living art museum for tourists (modern-day pilgrims), a lively university town, and the seat of the newly restored Galician Autonomous Government. The city is the narrative space in a symbolic search for collective marks of identity through architecture, geography, history, legends, food, and popular customs" (p. 181, my italics). Transferred to the Bresciano series, this view may well help to provide a centred re-reading of the seven 
novels, no longer in terms of their common "distractor", the human protagonist, Giovanni Bresciano, but for their re-construction of a historical Gibraltar - vide Reigosa's contemporary Santiago de Compostela - as a narrative "museumification" of the territory. Read within this frame, the Bresciano novels may then be seen to lay out the foundations of the Gibraltar as it may once have been in earlier days, and reveal links and disjunctive moments across the several centuries that find their contemporary meaning in the lived lives of the present-day community.

\section{Conclusion}

Whilst political commentators have frequently debated the emergence of a definitively "new" communal Gibraltarian identity", the detection of a new "national" literary culture may well prove to be complicated by the continued emergence, or potentially also disappearance, of narratives that will contribute sufficiently and substantially to that literature. In Gibraltar's case, the future remains uncertain. On the one hand, M.G. Sanchez's writing displays a continuing strength and versatility, but the collaboration of the two older writers, Benady and Chiappe, has recently ended with the publication of their seventh "Bresciano" novel, and it remains to be seen whether new narratives will be published by them or by others that will take the process forward of creating a new "national" literature. Despite this uncertainty, the present article has, it may be hoped, provided the basis of a rationale for studying the emergence of a new communal literary voice such as that of Gibraltar.

\section{Notes:}

1. See John A Stotesbury 2014, "The Rock and the Barbary Macaque in 21st-Century Gibraltarian Fiction in English”, The European English Messenger 23.2: 34-39.

2. The Franco régime in Spain imposed a total blockade of Gibraltar that was not lifted in its entirety until 1985, ten years after Franco's death.

3. For a detailed historical and contemporary linguistic account of the language situation in Gibraltar, see, e.g., David Levey (2008), Language Change and Variation in Gibraltar, Amsterdam: John Benjamins.

4. César Domínguez, "Historiography and the Geo-Literary Imaginary. The Iberian Peninsula: Between Lebensraum and Espace Vécu", in Fernando Cabo Aseguinolaza, Anxo Abuín Gonzalez, and César Domínguez, eds., A Comparative History of Literatures in The Iberian Peninsula, vol. 1, Amsterdam: John Benjamins, 2010, p. 114.

5. Trino Cruz Seruya, qtd in Aseguinolaza et al., p. 114. 
6. M.G. Sanchez in interview with Esterino Adami (2014) original English transcript of email interview published in Italian at: $<$ http://aperto.unito.it/handle/2318/150037 \#.VQCoruFVI5x>.

7. M.G. Sanchez, "If You Don't Write Your Own Stories, Others Will," New Statesman, 17 Feb. 2015, Web.

8. See, especially, Sam Benady, Sherlock Holmes in Gibraltar, Grindon, UK: Gibraltar Books, 1990 [short fiction]; Sam Benady, The Keys of the City: An Episode in the History of Gibraltar, Gibraltar: Gibraltar Books, 2005 [novel]; and Mary Chiappe, Mosaic of an Unquiet Time, Gibraltar: Doma', [2012].

9. John A Stotesbury, unpublished email interview with Sam Benady and Mary Chiappe, 4 Feb. 2015; until retirement, Benady was a lifelong paediatrician, while Chiappe worked in politics and education.

10. William Lempriere subsequently published his travelogue, A Tour from Gibraltor (sic) to Tangier, Sallee, Mogodore, Santa Cruz, Tarudant and thence over Mount Atlas to Morocco (London, 1791).

11. Personal email with the author, 9 Feb. 2015.

12. See, e.g., the compilation of general reviews at http://manilvalife.com/179/, [Accessed 6 Apr. 2015].

13. Sam Benady, Personal email, 4 Feb. 2015.

14. See Marilyn Stasio, "Crime/Mystery; Murder Least Foul: The Cozy, Soft-Boiled Mystery," The New York Times, Web, 18 Oct. 1992; see also "Cozy Mystery List: A Guide to Cozy Mystery (and Other Favourite) Books and DVDs," Accessed March 2015.

15. Email interview with the author, 4 Feb. 2015.

16. Benady's earlier historical novel, The Keys of the City: An Episode in the History of Gibraltar (2005), is due to appear in Spanish translation in 2015.

17. See, e.g., F. Oliva, The Frontiers of Doubt: A Critique of the Political System by a Gibraltarian Sceptic (2004).

\section{References:}

1. Adami, E. (2014) Original English Transcript of Email Interview with M.G. Sanchez. published in Italian. Available at: $<$ http://aperto.unito.it/handle/2318/15003 7\#.VQCoruFVI5x $>$ [Accessed May 2015].

2. Anon. (2015) Manilva Life. / Anonymous informal review of Sam Benady and Mary Chiappe, The Prince's Lady, Available at: $<$ http://manivaalife.com/179/> [Accessed April 2015].

3. Benady, S. (2015) Personal Email Communication with John A Stotesbury, 4 Feb.

4. Benady, S. (2015) Personal Email Communication with John A Stotesbury, 9 Feb. 
5. Christian, Ed. (ed.) (2001) The Post-Colonial Detective. Basingstoke. UK: Palgrave.

6. Colmeiro, J.F. (2001) The Spanish Detective as Cultural Other. // The Post-Colonial Detective. / Ed. by Ed. Christian, pp. 176-192.

7. Domínguez, C. (2010) Historiography and the Geo-Literary Imaginary. The Iberian Peninsula: Between Lebensraum and Espace Vécu. // A Comparative History of Literatures in the Iberian Peninsula. Vol. 1. / Ed. by F.C. Aseguinolaza, A.A. Gonzalez, and C. Domínguez. Amsterdam: John Benjamins, pp. 53-132.

8. Levey, D. (2008) Language Change and Variation in Gibraltar. Amsterdam: John Benjamins.

9. Knight, S. (2010) Crime Fiction since 1800: Detection, Death, Diversity. 2nd ed.. Basingstoke, UK: Palgrave.

10. Sanchez, M.G. (2015) If You Don't Write Your Own Stories, Others Will. // New Statesman, 17 Feb., Web.

11. Stasio, M. (1992) Crime/Mystery; Murder Least Foul: The Cozy, Soft-Boiled Mystery. / The New York Times, 18 Oct., Web.

12. Stotesbury, J.A. (2014) The Rock and the Barbary Macaque in 21st-Century Gibraltarian Fiction in English. // The European English Messenger 23.2: pp. 34-9.

13. Stotesbury, J.A. Unpublished email interview with Sam Benady and Mary Chiappe, 4 Feb.

\section{Sources of Data:}

1. Benady, S. (2005) The Keys of the City: An Episode in the History of Gibraltar. Gibraltar: Gibraltar Books.

2. Benady, S. and Chiappe, M. (2010) The Murder in Whirligig Lane. Gibraltar: Calpe Press.

3. Benady, S. and Chiappe, M. (n.d. [2011]) Fall of a Sparrow. Gibraltar: HKB Press.

4. Benady, S. and Chiappe, M. (n.d. [2011]) The Pearls of Tangier. Huntingdon, UK: Rock Scorpion Books.

5. Benady, S. and Chiappe, M. (n.d. [2012]) The Prince's Lady. Gibraltar: Two Pillars Press.

6. Benady, S. and Chiappe, M. (2013) The Devil's Tongue. Gibraltar: Two Pillars Press.

7. Benady, S. and Chiappe, M. (2014) Death in Paradise Ramp. Gibraltar: Two Pillars Press.

8. Benady, S. and Chiappe, M. (2015) The Dead Can't Paint: Bresciano and the French Inheritance. Gibraltar: Two Pillars Press. 


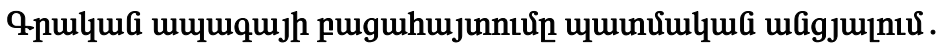

Shpnuipunjua ưuununıpjnıG

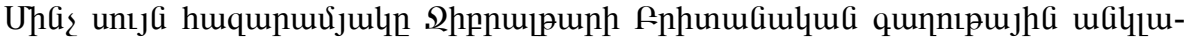

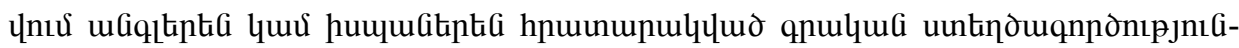

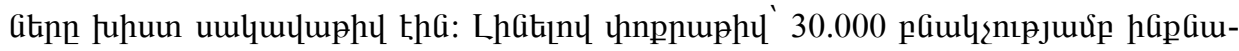

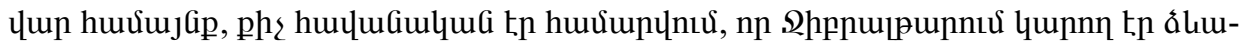

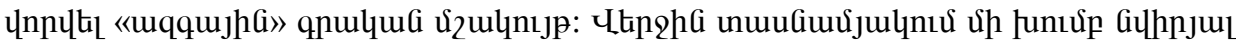

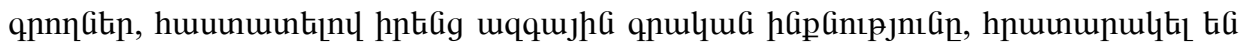

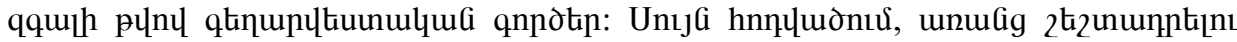

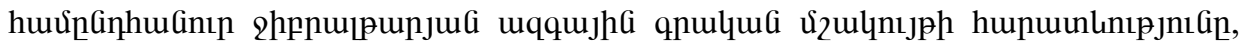

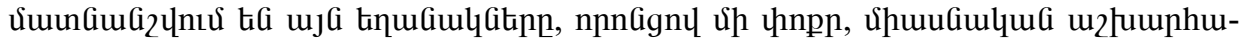

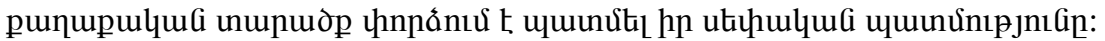

\section{Раскрытие литературного будущего в историческом прошлом: Гибралтарская история}

Число опубликованных литературных произведений на английском или испанском языках в британском колониальном анклаве Гибралтара было небольшим вплоть до наших дней. Считалось не очень вероятным, что в Гибралтаре, который был малочисленным автономным сообществом с населением в 30000 человек, могла сформироваться “национальная” литературная культура. В течение последнего десятилетия группа преданных делу писателей опубликовала достаточно много художественных произведений с целью утвердить свою “национальную” идентичность в литературе. В данной статье, не акцентируя факта существования гибралтарской литературной культуры, мы попытались показать, как небольшая единая геополитическая территория представляет собственную историю. 